\title{
Self-repairing of concrete cracks by using bacteria and basalt fiber
}

\author{
Kunamineni Vijay ${ }^{1}$ Meena Murmu ${ }^{1}$ \\ (c) Springer Nature Switzerland AG 2019
}

\begin{abstract}
Concrete is a most extensively used material in construction; however, cracks in concrete are unavoidable. There is a new technology that can heal the cracks by precipitated calcium carbonate called as microbial self-healing concrete which reduces the coefficient of permeability. The self-healing/self-repairing concrete with the addition of fibers can be used in construction industries to enhance the strength and durability of concrete. Fibers may reduce the crack width by bridging action and bacteria develop a filling material in that bridge portion. This improves the durability and strength of bacterial concrete. In the present study, four different mixes are prepared, namely normal concrete, bacterial concrete, fiber-reinforced concrete, and bacterial concrete, with the addition of fibers. The healing/repairing efficiency of concrete is measured in terms of electrical resistivity and compressive strength of concrete on pre-cracked samples and healed samples. Further, the results are correlated with the scanning electron microscope and energy-dispersive $\mathrm{X}$-ray spectrometer analysis. The results and analysis that carried out show substantial enhancement in the durability and strength of concrete with the addition of fibers in bacterial concrete.
\end{abstract}

Keywords Bacteria $\cdot$ Basalt fiber $\cdot$ Crack repairing $\cdot$ Strength $\cdot$ Durability

\section{Introduction}

In construction industry, concrete is the most extensively utilized material in the world and is the second most consumable material after water. Concrete is strong in compression and week in tension and has limited ductility, and cracks in concrete are inevitable [1]. There are so many repairing techniques accessible to repair the concrete structures. The development of cracks reduces the life span of concrete. The repairing costs of concrete structures are increasing day by day. A study estimates that the expense of concrete production is $\$ 65$ to $\$ 80 / \mathrm{m}^{3}$, while that of repairing cracks and maintenance is approximately $\$ 147 / \mathrm{m}^{3}[2]$. However, these methods are not eco-friendly and not economic $[3,4]$.

It should be noted that, in case of reinforced concrete structures, cracks are generally not considered to be a failure or damage and cracking does not specify a safety problem. The concrete loses its ability to protect the reinforced steel against corrosion in case of wider crack lengths. One of the major reasons for permanent concrete structure failure is the corrosion of steel. Microcracks do not affect the strength of concrete at the initial time. However, micro-cracks result in the formation of a network of cracks and contribute largely to the concrete permeability. This results in a reduction of resistance of the concrete against the ingress of aggressive substances [5, 6]. In certain places like water sewage pipes and nuclear power plants, repairing of cracks manually is a tedious task and also hazardous [7]. In this regard, the self-repairing mechanism is utmost essential for this purpose. Further, the practical experiences and experimental investigations on cement materials demonstrated that cracks can be healed by themselves, termed as autogenous healing. The autogenous healing is observed in cracks of maximum width between 0.1 to $0.2 \mathrm{~mm}$. In young concrete, it was

Kunamineni Vijay, vijay.kunamaneni@gmail.com | 'Department of Civil Engineering, National Institute of Technology, Raipur 492010, India.

SN Applied Sciences (2019) 1:1344 | https://doi.org/10.1007/s42452-019-1404-5

Received: 9 August 2019 / Accepted: 1 October 2019 / Published online: 5 October 2019 
reported that $0.1-\mathrm{mm}$-wide cracks take several days for healing, whereas several weeks are required for $0.2-\mathrm{mm}$ wide cracks. The autogenous healing in younger concrete is possible due to more unhydrated cement. However, it is difficult for autogenous healing at later ages of concrete [8-10]. The research on preventing interventions to limit the formation of cracks has been increased in the recent past so as to achieve higher structural performance [11]; further, the monumental response to the degradation of concrete at the micro-level by adding the self-healing materials has also drawn the attention of researchers. For this purpose, different healing agents such as polymers and biotechnological healing agents are used in order to improve the durability and strength of concrete $[12,13]$. The increase in the focus of researchers in this aspect is depicted in Fig. 1 based on the publications in recent years $[1,8]$.

The concept of self-healing is a well-known ancient phenomenon [14, 15]. However, its capacity for the purpose of crack-healing is limited in most of the concrete structures $[16,17]$. In recent years, bacteria-precipitated $\mathrm{CaCO}_{3}$ has been an alternative and eco-friendly technique for self-healing of cracks $[18,19]$. This technique has been proposed by Jonkers et al. for self-healing without human interface [20,21]. In [22] observed that using bacteria in concrete healed most of the cracks (up to $0.3 \mathrm{~mm}$ ) in 5 days and fill the surface totally in 20 days. The contrast test applied to concrete in [23] reported the microbial concrete repair cracks of wider length up to $470 \mu \mathrm{m}$ while in control concrete $210 \mu \mathrm{m}$ only. Microbial concrete heals the cracks with the precipitated calcium carbonate. However, the properties of concrete after healing are not much improved. Also, limited literature reports regarding the performance of concrete after healing of cracks. In this regard, an endeavor has been made to examine the performance of concrete after healing of cracks. It is

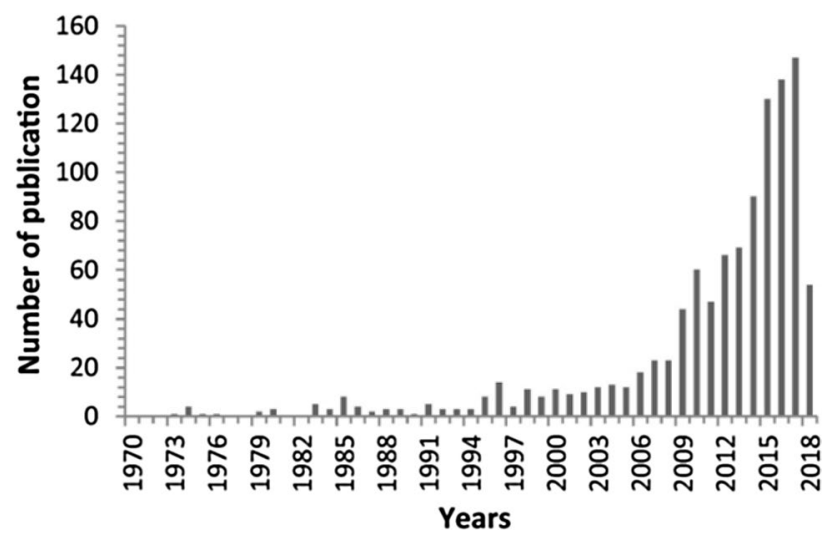

Fig. 1 Year-wise number of publications for phrase search "concrete healing" $[1,8]$ well known that the addition of fiber reduces the crack width and also the number of cracks in concrete by virtue of bridging action [24,25]. Hence, in this study basalt fibers have been used due to its eco-friendliness and high tensile strength. It also has the advantage of minimizing the crack widths and number of cracks by its bridging action and high tensile strength. The main objective of this paper is to study the self-repairing capacity of bacterial concrete with basalt fiber in it and investigations on the enhancement of durability and strength of concrete.

\section{Materials and methods}

\subsection{Materials}

In this study, ordinary Portland cement (OPC), fine aggregate, coarse aggregate, bacillus subtilis bacteria, basalt fiber, and calcium lactate are used for making the concrete. The OPC has been utilized in this study with 3.1 specific gravity and cement tested as per Indian Standards [26, 27]. Coarse aggregate of size less than $20 \mathrm{~mm}$ (20 $\mathrm{mm}$ nominal size) and Zone II fine aggregate were used with a specific gravity of 2.79 and 2.7 , respectively, confirming to Indian Standards [28, 29]. Normal portable water available in the laboratory has been used for the preparation of concrete. Bacillus subtilis bacteria are procured from Retron Pro Biotech Ltd., Vizag, and are shown in Fig. 2. The test details of bacteria are given in Table 1. From this, it is confirmed that the procured spores of bacillus subtilis are gram-positive bacteria. Based on the literature $[11,17], 10^{5} \mathrm{cfu} / \mathrm{ml}$ is the

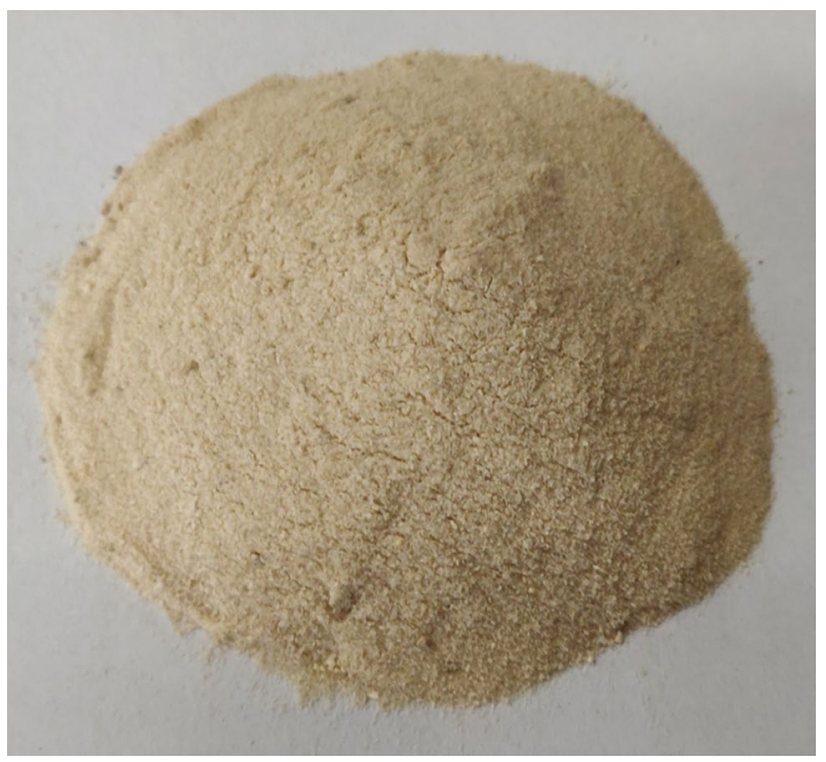

Fig. 2 Bacillus subtilis spore powder 
Table 1 Test data for identification of bacteria

\begin{tabular}{llll}
\hline Test performed & Indicator used & Color observation & Result \\
\hline Starch test & $\begin{array}{c}\text { Starch and lodine } \\
\text { Solution }\end{array}$ & $\begin{array}{c}\text { A dark color of the whole medium } \\
\text { except colony and its surrounding }\end{array}$ & Positive \\
Gram-staining reaction & Crystal violet & Purple & Gram positive
\end{tabular}

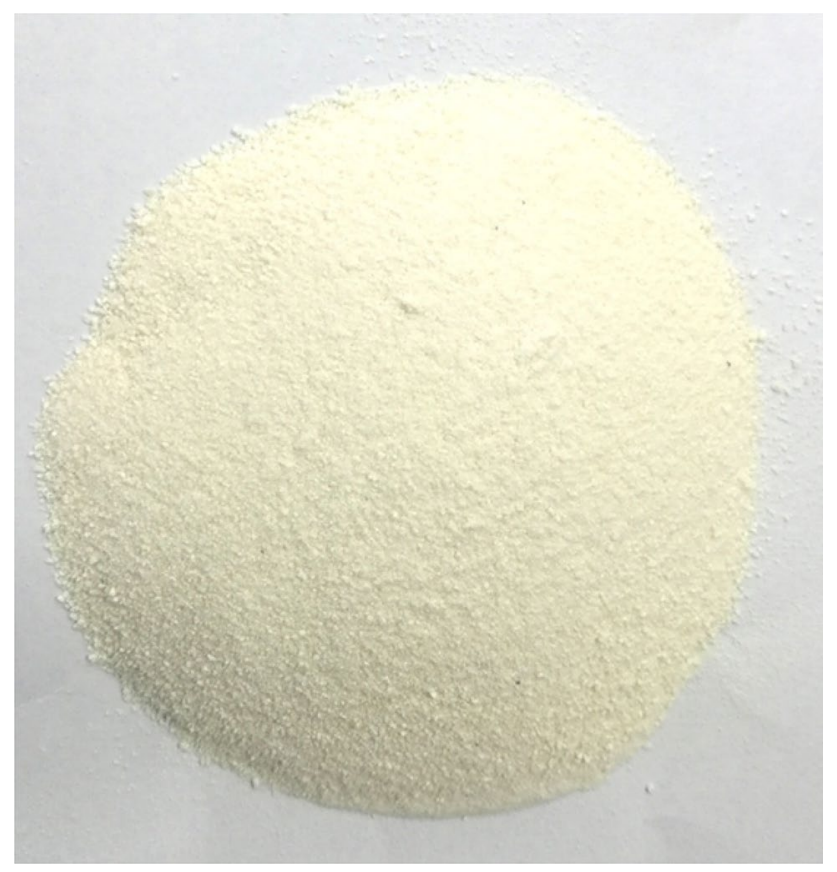

Fig. 3 Calcium lactate powder

Table 2 Physical properties of calcium lactate

\begin{tabular}{ll}
\hline Parameter & Value \\
\hline Appearance & White powder \\
Solubility & Soluble in water \\
Arsenic & $\leq 2$ parts per million \\
Heavy metals & $\leq 20$ parts per million \\
Iron & $\leq 80$ parts per million \\
Loss on drying & $23.50 \%$ \\
\hline
\end{tabular}

optimum concentration for improving the strength of concrete same concentration of bacteria which is used in this study. Calcium lactate is used as a nutrient source for bacteria; it was procured from Triveni Chemicals, Gujarat. Figure 3 shows the appearance of calcium lactate. The test details of the calcium lactate are given in Table 2. As per literature, [17] 0.5\% (w.r.t weight of cement) dosage of calcium lactate was added to concrete for better strength properties.

Basalt fiber used in this study is procured from the Hydro Design Management Co. Pvt. Ltd, Noida, and details
Table 3 Properties of basalt fiber

\begin{tabular}{ll}
\hline Parameter & Value \\
\hline Elastic modulus (GPa) & 93 \\
Tensile strength (MPa) & $3200-3850$ \\
Length (mm) & 12 \\
Specific gravity & 2.7 \\
\hline
\end{tabular}

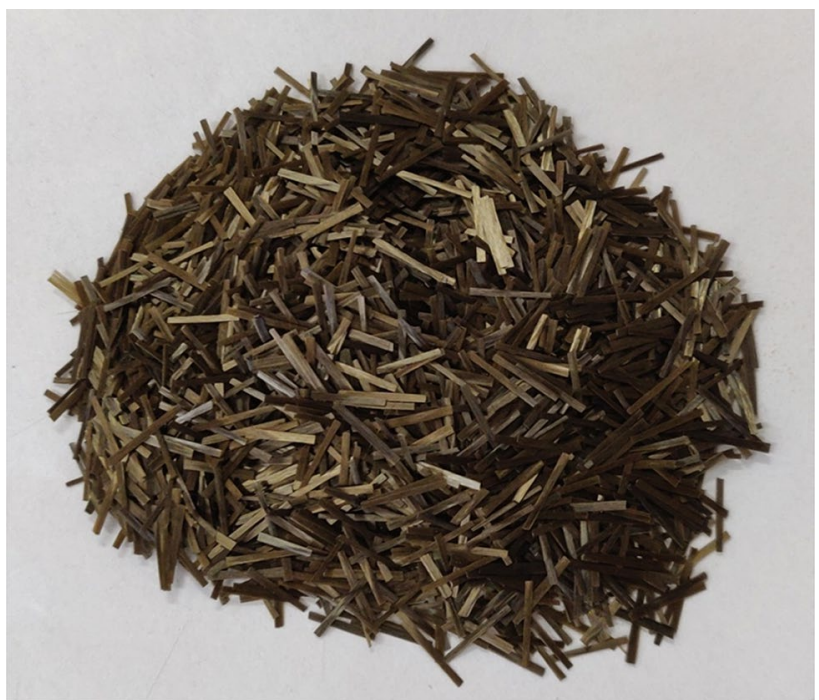

Fig. 4 Image of basalt fibers

of properties are given in Table 3. Figure 4 shows the appearance of basalt fibers used in this study.

\subsection{Concrete mix design}

In this study, OPC, fine aggregate, coarse aggregate, bacillus subtilis bacteria, basalt fiber, and calcium lactate are used for making the concrete. Three water-cement ratios $(0.45,0.4$, and 0.35$)$ are utilized to prepare the concrete mix. The concrete mixes were prepared as per Indian Standards IS: 10262-2009 [30]. The major variable in the concrete mix was water-cement ratio, and bacteria, calcium lactate, and basalt fiber are the additional materials. The mix design details are shown in Table 4, where the control concrete mix is denoted as Mix-1, basalt fiber-reinforced concrete is denoted as Mix-2, bacterial concrete is illustrated in Mix-3 that means concrete with the addition 
Table 4 Mix details of concrete per cubic meter

\begin{tabular}{|c|c|c|c|c|c|c|c|c|}
\hline Mix details & $\begin{array}{l}\text { Cement } \\
\left(\mathrm{kg} / \mathrm{m}^{3}\right)\end{array}$ & $\begin{array}{l}\text { Fine aggre- } \\
\text { gate }\left(\mathrm{kg} / \mathrm{m}^{3}\right)\end{array}$ & $\begin{array}{l}\text { Coarse aggre- } \\
\text { gate }\left(\mathrm{kg} / \mathrm{m}^{3}\right)\end{array}$ & Water $\left(\mathrm{kg} / \mathrm{m}^{3}\right)$ & $\begin{array}{l}\text { Bacteria } \\
\text { (cfu/ml) }\end{array}$ & $\begin{array}{l}\text { Calcium lac- } \\
\text { tate }\left(\mathrm{kg} / \mathrm{m}^{3}\right)\end{array}$ & $\begin{array}{l}\text { Fiber dosage } \\
\left(\mathrm{kg} / \mathrm{m}^{3}\right)\end{array}$ & $\begin{array}{l}\text { Chemical } \\
\text { admixture }(\mathrm{kg} / \\
\left.\mathrm{m}^{3}\right)\end{array}$ \\
\hline \multicolumn{9}{|l|}{$\mathrm{W} / \mathrm{C}=0.35$} \\
\hline Mix-1 & 450 & 593.03 & 1214.16 & 157.6 & Nil & Nil & Nil & 4.5 \\
\hline Mix-2 & 450 & 593.03 & 1214.16 & 157.6 & Nil & Nil & 4.05 & 4.5 \\
\hline Mix-3 & 450 & 593.03 & 1214.16 & 157.6 & $10^{5}$ & 2.25 & Nil & 4.5 \\
\hline Mix-4 & 450 & 593.03 & 1214.16 & 157.6 & $10^{5}$ & 2.25 & 4.05 & 4.5 \\
\hline \multicolumn{9}{|l|}{$W / C=0.4$} \\
\hline Mix-1 & 394 & 675.3 & 1227.5 & 157.6 & Nil & $\mathrm{Nil}$ & Nil & 3.152 \\
\hline Mix-2 & 394 & 675.3 & 1227.5 & 157.6 & Nil & Nil & 4.05 & 3.152 \\
\hline Mix-3 & 394 & 675.3 & 1227.5 & 157.6 & $10^{5}$ & 1.97 & $\mathrm{Nil}$ & 3.152 \\
\hline Mix-4 & 394 & 675.3 & 1227.5 & 157.6 & $10^{5}$ & 1.97 & 4.05 & 3.152 \\
\hline \multicolumn{9}{|l|}{$\mathrm{W} / \mathrm{C}=0.45$} \\
\hline Mix-1 & 359 & 703.13 & 1222.33 & 161.54 & Nil & Nil & Nil & 1.79 \\
\hline Mix-2 & 359 & 703.13 & 1222.33 & 161.54 & Nil & Nil & 4.05 & 1.79 \\
\hline Mix-3 & 359 & 703.13 & 1222.33 & 161.54 & $10^{5}$ & 1.795 & Nil & 1.79 \\
\hline Mix-4 & 359 & 703.13 & 1222.33 & 161.54 & $10^{5}$ & 1.795 & 4.05 & 1.79 \\
\hline
\end{tabular}

of $10^{5} \mathrm{cfu} / \mathrm{ml}$ bacteria and $0.5 \%$ (w.r.t weight of cement) of calcium lactate, and the bacterial concrete embedded with basalt fiber is denoted as Mix-4. The fresh and harden concrete properties are studied for all the concrete mixes as per the mix details in Table 4 to know the effect of bacteria and basalt fiber on properties concrete.

\subsection{Workability of concrete}

The property of fresh concrete as workability was measured by slump cone test and compaction factor (CF) test as per IS: 1199-1956. The slump value indicates the stiffness of the fresh mix to work with. Another popular and commonly used test to know the workability of concrete is the CF test. The test results of the CF are more sensitive and reliable for low workable mixes.

\subsection{Mechanical properties}

The harden properties of concrete are measured by compressive and flexural strength tests. The compressive strength of concrete was tested on $100 \times 100 \times 100 \mathrm{~mm}$ size cubes as per IS: 516-1959 [31]. The flexural strength of concrete was tested on beam samples of standard dimensions $500 \times 100 \times 100 \mathrm{~mm}$ as per IS: $516-1959$. The compressive strength is tested at an age of 7,28 , and 56 days of water cured samples by utilizing compression testing machine. The flexural strength is tested at an age of 28and 56-day water cured samples. For determination of compressive and flexural strengths, the average value of three samples is taken.

\subsection{Electrical resistivity of concrete}

The electrical resistivity test on concrete was performed to know the quality of concrete in terms of voids and internal cracks. The test has been performed at an age of 7-, 28-, and 56-day cured samples, and for each test, the average value of three samples is used for the determination of electrical resistivity of concrete. For the measurement of electrical resistance of concrete Leader $\mathrm{RCON}^{\mathrm{TM}}$ has been used at a predetermined location. The test has been performed on three cubes for each mix in three different conditions: undamaged samples, damaged samples, and healed samples. The electrical resistivity $(\rho$ in $\Omega \cdot m)$ of concrete for an average value of electrical resistance ( $R$ in $\Omega \cdot$ ), length ( $\mathrm{in} \mathrm{m}$ ) and area ( $\mathrm{A}$ in $\left.\mathrm{m}^{2}\right)$ is given by [17]:

$\rho=\frac{R A}{l}$

\subsection{Microstructure analysis}

For analyzing the microstructure of concrete, SEM analysis has been carried out on ZEISS SEM machine. The 28-day cured samples are collected and immersed in acetone to stop the further hydration process. These collected samples are prepared with the size of 1-cm cubes with smooth surface. These samples have been coated with gold in sputter coater for obtaining high-resolution SEM images. Simultaneously, EDX analysis is performed for knowing the major elements present on the surface. 


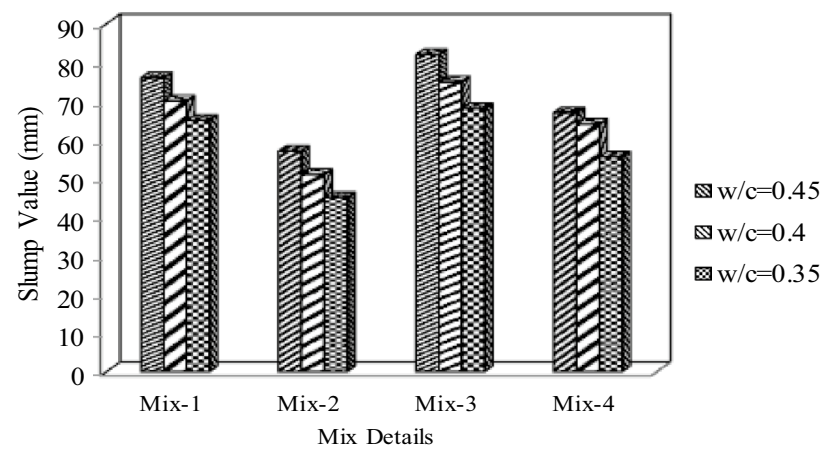

Fig. 5 Slump cone test results of different concrete mixes

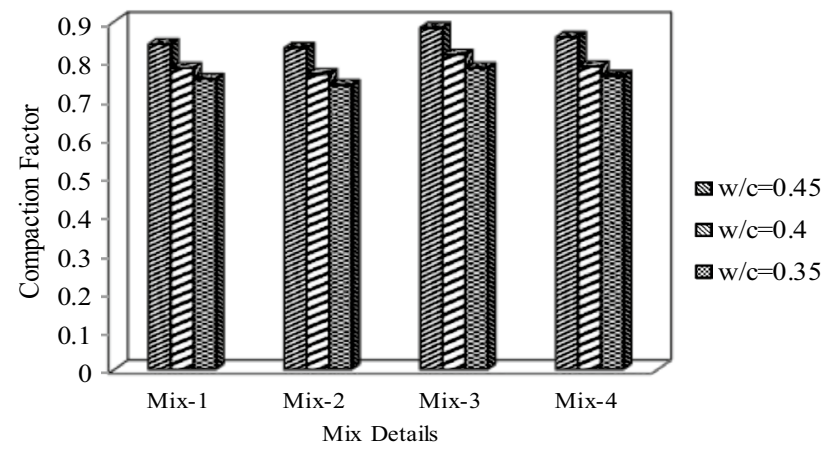

Fig. 6 Compaction factor test results of different concrete mixes

\subsection{X-ray diffraction (XRD) analysis for the deposited material at the cracks}

The deposited material at the crack is collected from the concrete samples to know the chemical composition using XRD analysis. The collected samples were ground and sieved from 75 microns.

\section{Results and discussion}

\subsection{Workability of concrete}

The combined effect of bacteria, calcium lactate, and basalt fiber on workability of concrete mix has been examined. Figures 5 and 6 illustrate the experimental results for workability of concrete. The results show that the addition of calcium lactate increases the slump value, while, the basalt fiber decreases the slump value of respective concrete. The addition of bacteria, calcium lactate, and basalt fiber together gives slump value more than the basalt fiber-reinforced mix and shows a good workability. From Fig. 6 , it is noticed that similar results have been obtained for compaction factor tests also. Similar to normal concrete mix, the bacterial concrete also shows a proportional change in workability with water-cement ratio. The calcium lactate works as a retarding agent in concrete; it increases the setting time and fluidity of concrete [15]; due to this, the workability of bacterial concrete increases, whereas basalt fibers absorb certain moisture content during the mixing and also increase the friction between fibers and cement [32]. This activity decreases the workability of basalt fiber-reinforced concrete and bacterial concrete embedded with basalt fiber. The addition of basalt fiber, bacteria, and calcium lactate gives good workable concrete nearly same as normal concrete.

\subsection{Mechanical properties of concrete}

The strength results of concrete are depicted in Figs. 7 and 8 . The compressive strength is significantly improved in bacterial concrete and bacterial concrete embedded with basalt fiber. Similar trend has been followed in flexural strength also. Figure 7 confirms that microbial activity plays an important role in improving the compressive
Fig. 7 Compressive strength results of different concrete mixes

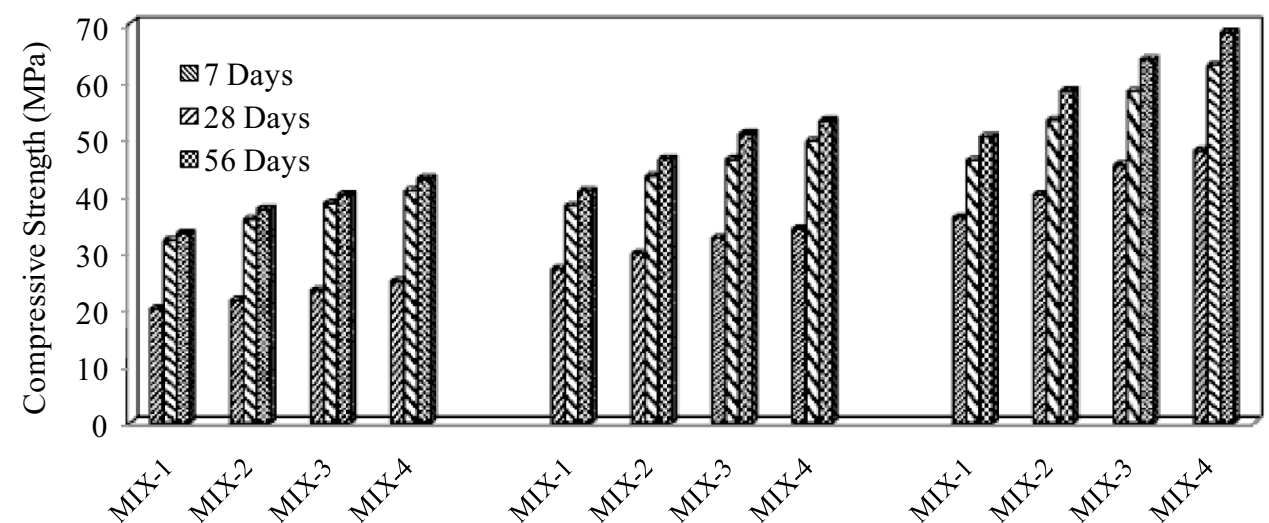

Mix Details (For 0.45 w/c) Mix Details (For 0.4 w/c)
Mix Details (For $0.35 \mathrm{w} / \mathrm{c}$ )

SN Applied Sciences A SPRINGER NATURE journa 
Fig. 8 Flexural strength results of different concrete mixes

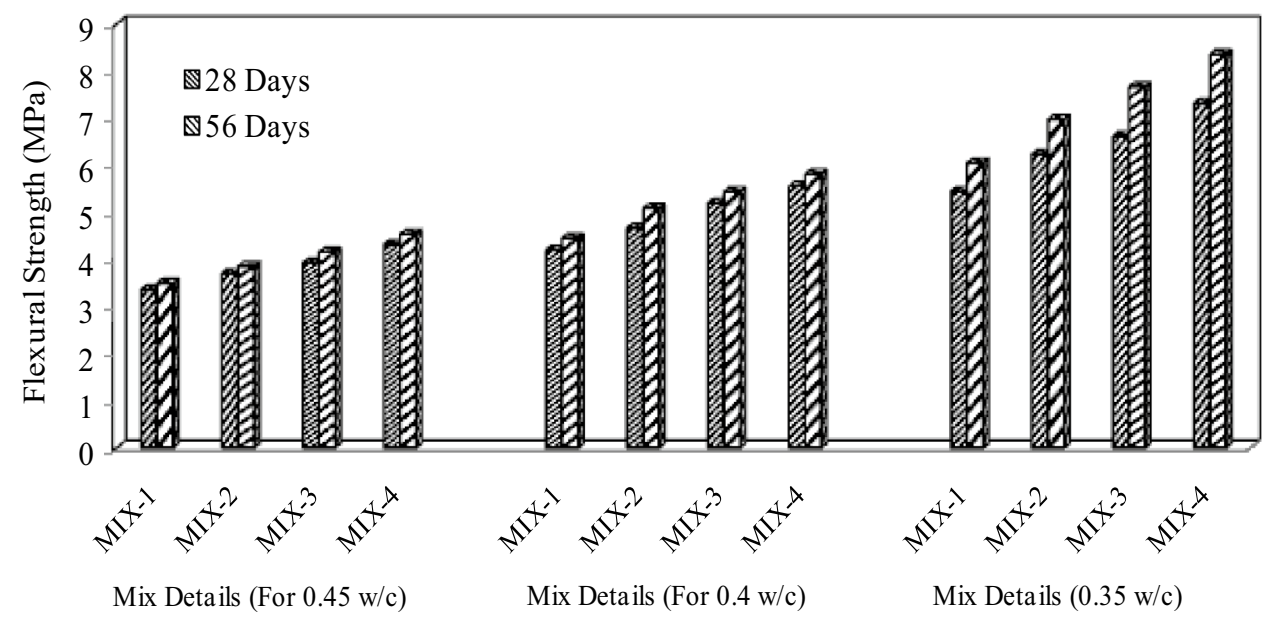

addition of fibers shows the improvement in strength and the workability is nearly equal to normal concrete.

For knowing the recovery properties of concrete after healing, the concrete samples are damaged by applying $60 \%$ of load-carrying capacity at an age of 28 days. Further these cubes are kept in water curing for healing purpose. After 28 days compressive strength was determined for healed samples and compared with the undamaged samples at an age of 56 days. Figure 10 shows the comparison of healed samples compressive strength that was subjected to damage by preloading and undamaged samples at an age of 56 days. Bacterial concrete shows considerably higher strengths after healing as compared to control mix. The strength recovery of bacterial concrete with the addition of basalt fiber shows better results than all the other concrete mixes. The strength difference in 56 days for undamaged samples and healed samples can be measured as the unrecovered strength. The unrecovered strength in Mix 4 is $16.7 \%$, whereas in MIX 1 it is $30.75 \%$ for 0.4 water-cement ratio. The unrecovered strength in bacterial concrete and bacterial concrete with addition of fibers is very little. It confirms that the recovery rate is very high in bacterial concrete and bacterial concrete with basalt fibers as compared to other mixes. Bacterial concrete and bacterial concrete with the addition of basalt fibers show good results in recovery of concrete properties after preloading.

\subsection{Electrical resistivity of concrete}

The electrical resistivity test on concrete was performed to know the quality of concrete in terms of voids and internal cracks. The test has been performed at an age of 7-, 28-, and 56-day cured samples. The results obtained are listed in Fig. 11. The results validate the significant improvement in electrical resistivity of bacterial concrete embedded with basalt fiber. The concrete possesses 


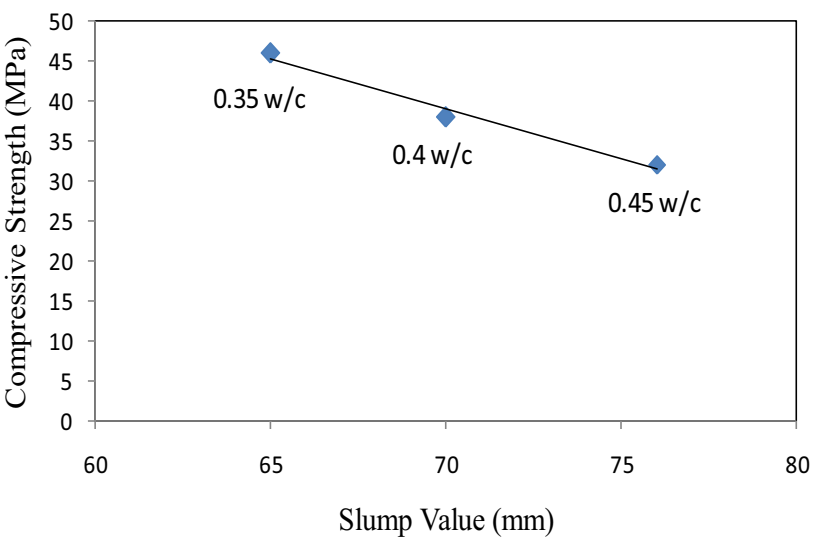

(a)

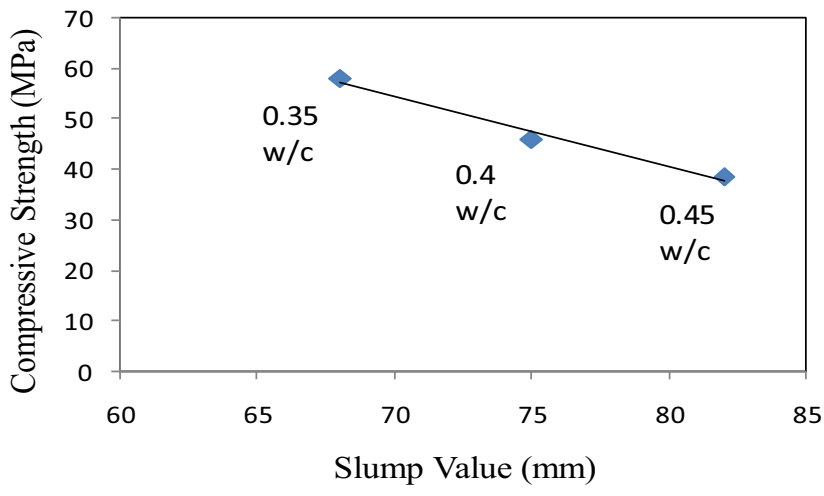

(c)

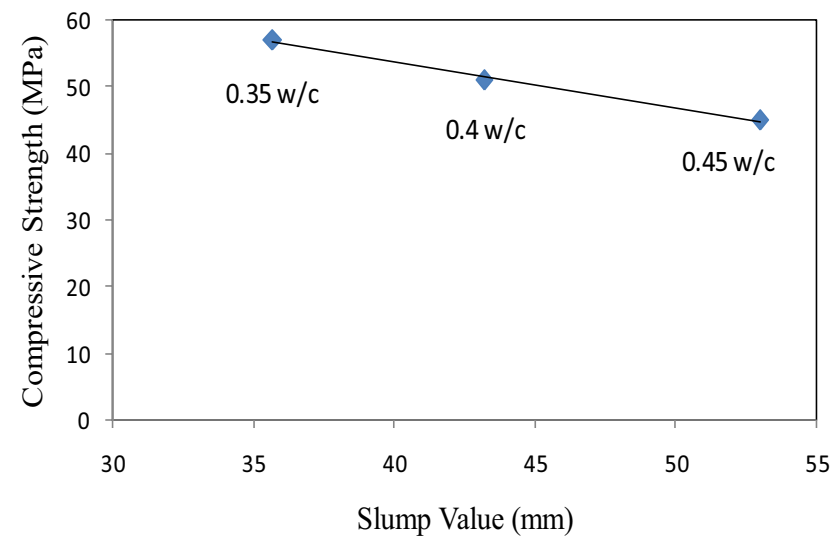

(b)

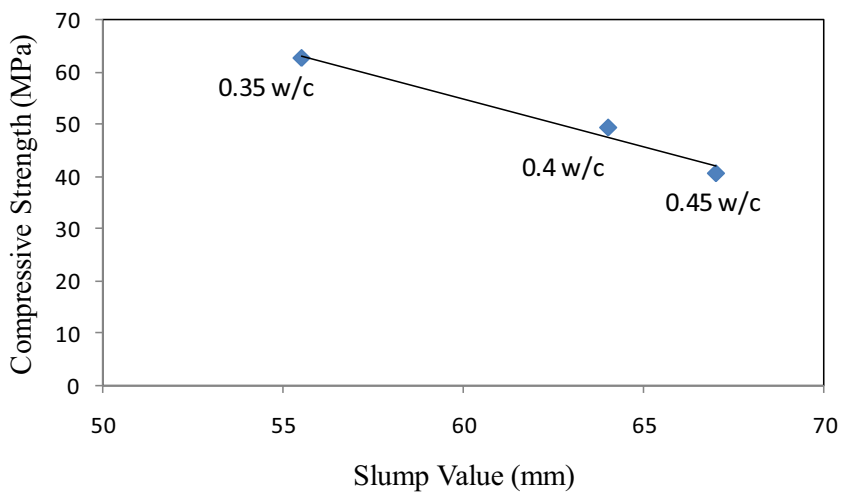

(d)

Fig. 9 Relationship between workability and compressive strength of concrete for: a MIX 1, b, MIX 2 c MIX 3, d MIX 4

Fig. 10 Comparison of compressive strength of healed samples damaged by preloading and undamaged samples at an age of 56 days

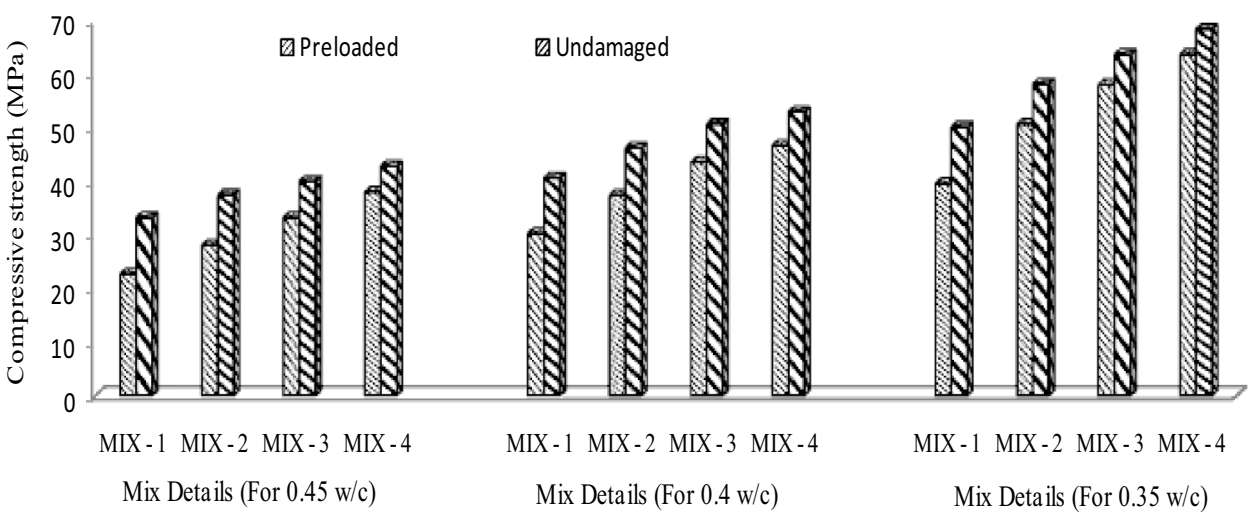

The cubes are pre-cracked by applying the compression load at an age of 28 days, and these cubes are kept water curing for healing purpose. The electrical resistivity test has been performed on preloaded (pre-cracked) cubes, and the same test has been performed on healed concrete samples for knowing the rate of self-repairing of concrete. Figure 12 depicts the results of pre-cracked and healed samples at an age of 28 days and 56 days. 
Fig. 11 Electrical resistivity of different concrete mixes

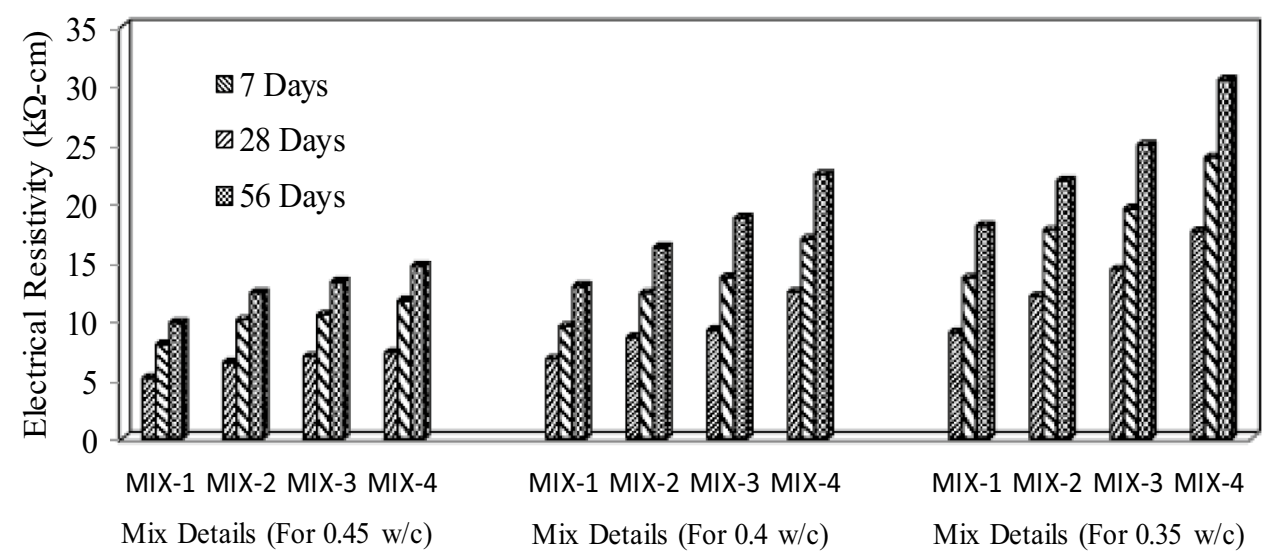

Fig. 12 Electrical resistivity results of pre-cracked and healed samples

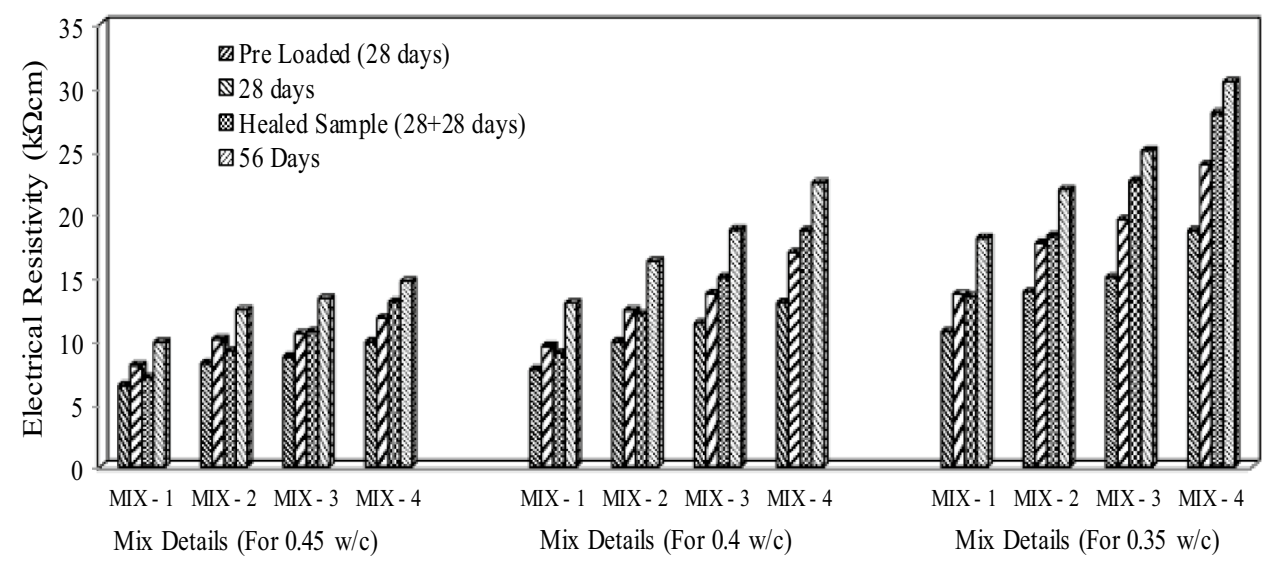

The self-repairing capacity of concrete has been greatly enhanced with bacteria and basalt fiber. The healing percentage is high in concrete with lower water-cement ratio as compared to higher water-cement ratios in the presence of bacteria and basalt fiber. This is due to the production of more $\mathrm{CaCO}_{3}$ and the basalt fiber, which acts as a bridging material between cracks.

\subsection{Micro structure analysis}

The SEM and EDX analyses of normal and bacterial concrete are illustrated in Fig. 13. It is noticed that the presence of tetrahedron and pyramid shapes in bacterial concrete shows the presence of calcite. It means the pores in concrete mix are filled with deposited calcite, resulting in enhancement of durability and strength of concrete [21, 22]. From EDX analysis, it is noticed that the amount of Ca is obtained for bacterial concrete which is higher than control concrete. The elemental analysis confirms the presence of higher amount of $\mathrm{Ca}$ in bacterial concrete. SEM and EDX analyses confirm the presence of $\mathrm{CaCO}_{3}$ in bacterial concrete. This fills pores and tiny cavities in concrete and improves the durability and strength of concrete.

\subsection{X-ray diffraction (XRD) analysis for the deposited material at the cracks}

XRD analysis was done for the deposited material at the cracks after healing the cracks. Figure 14 shows that the XRD analysis of deposited material. From Fig. 14 it is noticed that the crystalline peaks are present at an angle (2Ө) of $29.6^{\circ}, 36.2^{\circ}, 39^{\circ}$ and $47.7^{\circ}$. These peaks represent the presence of calcite in the material. The formation of calcite by bacteria is the reason for the improved durability and strength of concrete after healing the cracks.

\section{Conclusions}

The investigation of using bacteria along with basalt fiber in concrete for improving and recovery of concrete properties of damaged samples has been explored in this paper. Workability, mechanical properties, and recovery of strength for samples healed by $\mathrm{CaCO}_{3}$ precipitation by microbes have been investigated. The addition of basalt fiber in bacterial concrete enhances the compressive strength as well as flexural strength. The workability 


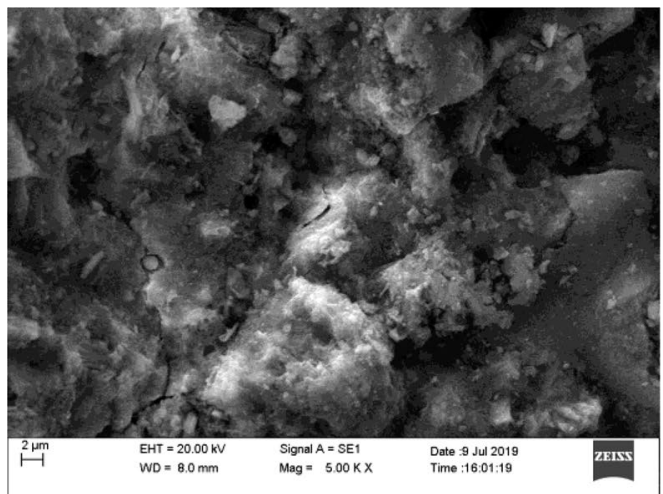

(a)

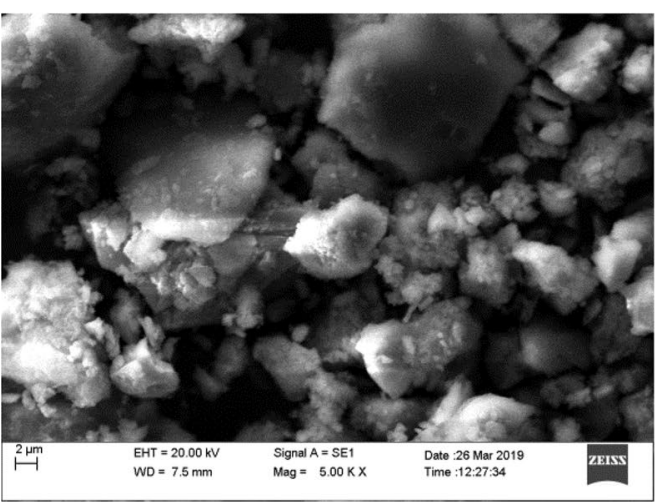

(b)

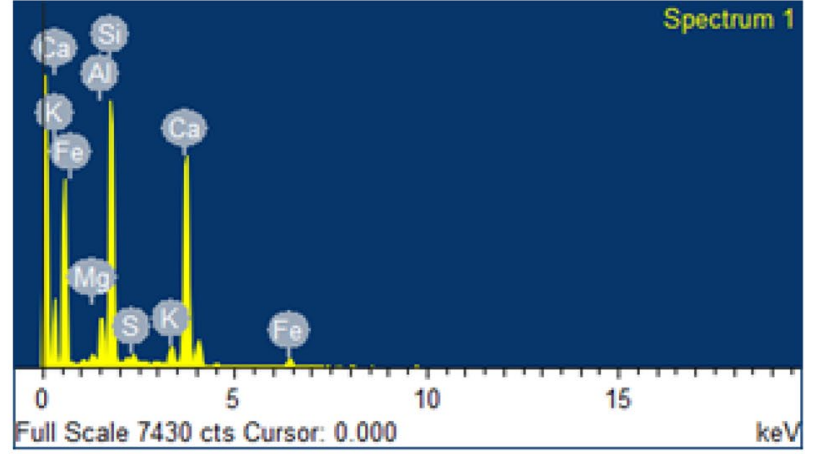

(c)

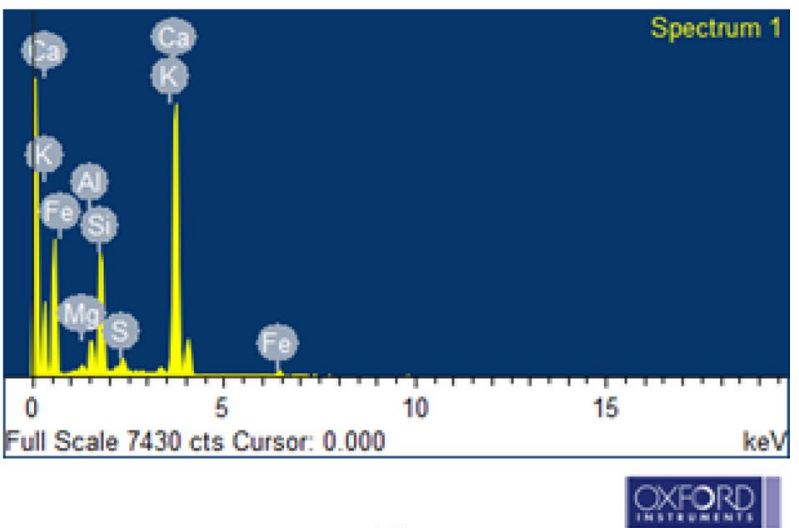

(d)

Fig. 13 SEM analysis of $\mathbf{a}$ control concrete and $\mathbf{b}$ bacterial concrete, and EDX analysis of $\mathbf{c}$ control concrete and $\mathbf{d}$ bacterial concrete

Fig. 14 XRD analysis of deposited material at cracks after healing

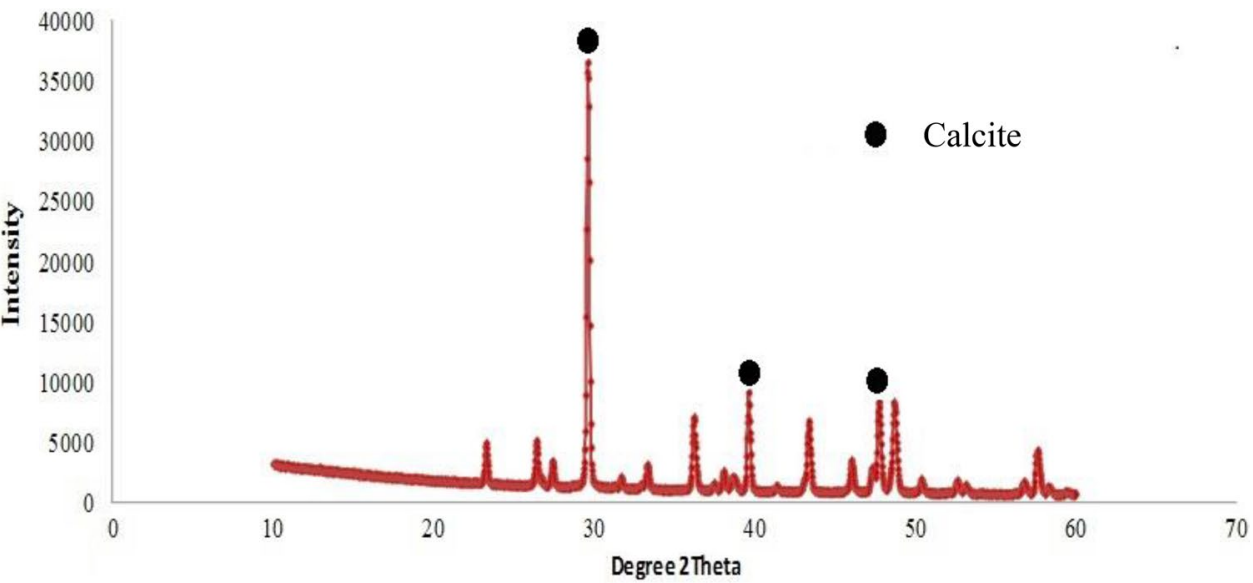

slightly decreases with the addition of basalt fiber; however, bacterial concrete shows good workability even with the addition of basalt fibers. The addition of basalt fiber contributes to the recovery of properties of healed samples. SEM analysis of concrete confirms the presence of calcite in bacterial concrete. The calcite fills the voids and micro-cracks in concrete and enhances the concrete performance. The compressive strength has been observed to be recovered using basalt fiber in bacterial concrete. The electrical resistivity test results also conforms the recovery of concrete properties after healing the cracks. Further XRD analysis also confirms that the deposited material in the cracks is calcite; this is the reason for improving the recovery properties of concrete 
after healing. The experimental results confirm the addition of basalt fiber in bacterial concrete, which improves the performance of concrete.

\section{Compliance with ethical standards}

Conflict of interest The authors declare that they have no conflict of interest.

\section{References}

1. Van Tittelboom K, De Belie N (2013) Self-healing in cementitious materials-a review. Materials 6:2182-2217

2. Sidiq A, Gravina RJ, Setunge S, Giustozzi F (2019) Microstructural analysis of healing efficiency in highly durable concrete. Constr Build Mater 215:969-983

3. Krishnapriya S, Babu DLV, Prince Arulraj G (2015) Isolation and identification of bacteria to improve the strength of concrete. Microbiol Res 174:48-55

4. Issa CA (2009) Methods of crack repair in concrete structures. Woodhead Publishing Limited, Sawston

5. Siad A, Bencheikh M, Hussein L (2017) Effect of combined precracking and corrosion on the method of repair of concrete beams. Constr Build Mater 132:462-469

6. Yang Z, Hollar J, He X, Shi X (2010) Laboratory assessment of a self-healing cementitious composite. Transp Res Rec J Transp Res Board 2142:9-17

7. Yusa N, Chen Z, Miya K (2005) Sizing of stress corrosion cracking on austenitic stainless piping in a nuclear power plant from eddy current NDT signals. Nondestruct Test Eval 20(2):103-114

8. Sidiq A, Gravina R, Giustozzi F (2019) Is concrete healing really efficient? A review. Constr Build Mater 205:257-273

9. Yang Y, Yang E, Li VC (2011) Autogenous healing of engineered cementitious composites at early age. Cem Concr Res 41(2):176-183

10. Qureshi T, Kanellopoulos A, Al-tabbaa A (2018) Autogenous selfhealing of cement with expansive minerals-I : impact in early age crack healing. Constr Build Mater 192:768-784

11. Mondal S, Ghosh AD (2018) Investigation into the optimal bacterial concentration for compressive strength enhancement of microbial concrete. Constr Build Mater 183:202-214

12. Van Tittelboom $K$, Tsangouri E, Van Hemelrijck D, De Belie N (2015) The efficiency of self-healing concrete using alternative manufacturing procedures and more realistic crack patterns. Cem Concr Compos 57:142-152

13. Chahal N, Siddique R, Rajor A (2012) Influence of bacteria on the compressive strength, water absorption and rapid chloride permeability of fly ash concrete. Constr Build Mater 28(1):351-356

14. Jacobsen S, Sellevold EJ (1996) Self healing of high strength concrete after deterioration by freeze/thaw. Cem Concr Res 26(1):55-62
15. Vijay K, Murmu M, Deo SV (2017) Bacteria based self healing concrete-a review. Constr Build Mater 152:1008-1014

16. Reinhardt $H$, Jooss $M$ (2003) Permeability and self-healing of cracked concrete as a function of temperature and crack width. Cem Concr Res 33:981-985

17. Vijay K, Murmu M (2019) Effect of calcium lactate on compressive strength and self-healing of cracks in microbial concrete. Front Struct Civ Eng 13(5):515-525

18. De Muynck W, De Belie N, Verstraete W (2010) Microbial carbonate precipitation in construction materials: a review. Ecol Eng 36(2):118-136

19. Van Tittelboom K, De Belie N, De Muynck W, Verstraete W (2010) Use of bacteria to repair cracks in concrete. Cem Concr Res 40(1):157-166

20. Jonkers HM, Thijssen A, Muyzer G, Copuroglu O, Schlangen E (2010) Application of bacteria as self-healing agent for the development of sustainable concrete. Ecol Eng 36:230-235

21. Jonkers $H$, Schlangen $E$ (2008) Development of a bacteria-based self healing concrete. Tailor Made Concr Struct. https://doi. org/10.1201/9781439828410.ch72

22. Luo M, Qian CX, Li RY (2015) Factors affecting crack repairing capacity of bacteria-based self-healing concrete. Constr Build Mater 87:1-7

23. Wiktor V, Jonkers HM (2010) Self-healing of cracks in bacterial concrete. In: 2nd International symposium on service life design for infrastructures, pp 825-831

24. Ju M, Park Y, Park C (2017) Cracking control comparison in the specifications of serviceability in cracking for FRP reinforced concrete beams. Compos Struct 182:674-684

25. Augusto L, Borges C, Monte R, Alan D, Rambo S, De Figueiredo AD (2019) Evaluation of post-cracking behavior of fiber reinforced concrete using indirect tension test. Constr Build Mater 204:510-519

26. BIS. 8112 (1989) Indian Standard 43 Grade ordinary portland cement-specification. Bureau of Indian Standards

27. BIS. 4031 (1988) Methods of physical tests for hydraulic cement

28. BIS. 383 (2016) Specifications for coarse and fine aggregates from natural sources for concrete

29. BIS. 2386 (2016) Methods of test for aggregates for concrete

30. BIS. 10262 (2009) Guidelines for concrete mix design proportioning. Bureau of Indian Standards

31. BIS. 516 (1959) Indian standard methods of tests for strength of concrete. Bureau of Indian Standards

32. Raut N, Kawade U (2017) Conventional concrete by using basalt fiber. Int Res J Eng Technol 4:696-699

Publisher's Note Springer Nature remains neutral with regard to jurisdictional claims in published maps and institutional affiliations. 